\title{
In Vitro Antibakteri Ekstrak Etanol Puni (Zingiber zerumbet) Asal Pulau Timor
}

\author{
Origenes Boy Kapitan a , Laksmi Ambarsari ${ }^{\text {b }}$ dan Syamsul Falah ${ }^{c}$ \\ ${ }^{a}$ Fakultas Pertanian, Universitas Timor, Kefamenanu, TTU - NTT, Indonesia. \\ ${ }^{b}$ Pusat Penelitian Biofarmaka, Institut Pertanian Bogor, Bogor, Indonesia. \\ 'Departemen Biokimia, Fakultas Matematika dan Ilmu Pengetahuan Alam, Institut Pertanian Bogor, Bogor, Indonesia
}

Article Info

\section{Article history:}

Received 8 Januari 2017

Received in revised form 20 Februari 2017

Accepted 9 Maret 2017

Keywords:

Antibacterial activity

Extraction

Puni

Wild Ginger

Zingiber zerumbet

\section{Pendahuluan}

Tanaman Zingiberaceae mempunyai sifat aromatik dan efek farmakologis yang dipengaruhi oleh senyawa-senyawa metabolit sekunder pada rimpangnya (Voravuthikuncai et al. 2006). Salah satu anggota Zingiberaceae yang menjad daya tarik bagi para peneliti dunia karena beragamnya potensi pengobatan yang dikandung adalah Zingiber zerumbet (L.) Smith (Singh et al. 2012). Tanaman in tersebar di wilayah Asia Selatan, Asia Tenggara, Pasifik dan Oceania (Kress, et al. 2002; Kress, 2014). Di Indonesia, tanaman ini dikenal dengan sebutan lempuyang dan tersebar di wilayah Sumatra, Jawa dan Kalimantan. Tanaman in tumbuh dan diduga tersebar secara merata di pulau Timor serta hidup secara liar. Penduduk setempat mengenal tanaman ini dengan nama puni. Secara empirik, masyarakat di pulau Timor hanya memanfaatkan tanaman ini dalam penyembuhan luka borok secara topikal, sementara itu di beberapa daerah yang lain tanaman ini dimanfaatkan baik dalam kondisi ekstrak segar maupun ekstrak rebusan sebagai pembersih darah, obat disentri, nyeri perut, batu ginjal, sakit kuning, antelmintik, luka, obat borok, bisul, penurun bengkak, dan gatal-gatal, serta pereda nyeri (Sinaga et al. 2011)

Luka adalah kerusakan fisik akibat dari terbukanya atau hancurnya kulit yang menyebabkan ketidakseimbangan fungsi dan anatomi kulit normal. Terbukanya kulit mengakibatkan serangan mikroorganisme pada jaringan dan mengakibatkan infeksi. Infeksi lokal pada luka menjadi salah satu penyebab luka kronis sehingga membutuhkan waktu yang lama untuk proses penyembuhannya. Infeksi ini juga menjadi alasan terkuat bagi kegagalan proses penyembuhan luka Beberapa organisme penginfeksi yang teridentifikasi adalah Staphylococcus aureus, Streptococcus pyogenes, Corynebacerium sp, Escherichia coli dan Pseudomonas aeruginosa (Nagori dan Solanki, 2011).

Voravuthikuncai et al. (2006) melaporkan bahwa Z. zerumbet yang berasa dari Thailand diketahui efektif dalam menghambat bakteri $S$. aureus dengan nila konsentrasi hambat tumbuh minimum (KHTM) sebesar $0.79 \mathrm{mg} \mathrm{mL}^{-1}$. Sari et al (2013) melaporkan bahwa ekstrak segar Z. zerumbet asal Sumatra Bara mempunyai aktivitas antimikrob dengan daya hambat berturut-turut sebesar 9.13 mm; $9.20 \mathrm{~mm}$; dan $9.60 \mathrm{~mm}$ ketika diujikan pada mikrob uji $S$. aureus, E. coli, dan $C$. albicans. Uji antimikrob ekstrak kasar etanol terhadap 30 jenis patogen dan 3 jenis jamur menunjukkan bahwa tanaman $Z$. zerumbet asal wilayah Bangladesh mempunyai kemampuan yang sangat potensial sebagai antimikrob dengan kemampuan hambat sebesar 6-10 mm (Kader et al. 2011).

Kemampuan aktivitas antibakteri tanaman disebabkan oleh kandungan metabolit sekundernya yang dipengaruhi oleh kondisi lingkungan tumbuh tanaman. Secara empiris penggunaan rimpang Zingiber zerumbet oleh masyarakat di Timor dalam mengobati luka borok menjadi menarik untuk dikaji. Kondisi wilayah Pulau Timor yang kering dengan iklim semi arid membuat peneliti menduga adanya aktivitas senyawa-senyawa kimia aktif (metabolit sekunder) yang tinggi dalam menghambat pertumbuhan bakteri penyebab luka borok.

\section{Metode}

Penelitian dilakukan pada bulan Desember 2014 sampai Juli 2015 di Laboratorium Biokimia, Departemen Biokimia IPB dan Laboratorium Bakteriologi, Divisi Mikrobiologi Medik FKH IPB. Bahan yang digunakan dalam penelitian ini adalah rimpang Zingiber zerumbet segar yang dikoleksi pada bulan Juni dari wilayah Amarasi, Kabupaten Kupang, Nusa Tenggara Timur Untuk bakteri uji digunakan bakteri Eschericia coli, Pseudomonas aeruginosa, Staphylococcus aureus dan Bacillus subtilis. Bahan pendukung yang digunakan antara lain aquadest, alkohol 70\%, Fosfomisin (fosfomyacin), n-heksana, etil asetat, etanol 96\%, dimetilsulfoksida (DMSO), media Potato Dextrose Agar (PDA), media Nutrient Agar (NA), Nutrient Broth (NB), dan media Muelle Hinton Agar (MHA). Alat yang digunakan adalah timbangan digital (ACIS), blender, magnetic stirrer, rotavapor, cawan petri, tabung reaksi, erlenmeyer, pipet, gelas ukur, batang pengaduk, jarum ose, vortex mixer $\mathrm{XH}-\mathrm{D}$, autoklaf ( $\mathrm{N}$ Biotech. Inc), inkubator (Firlabo), shaker (N-Biotech. Inc), LCMS (Qmicro
QAA 642), jangka sorong (Varnier), pipet mikroliter (Gilsong), laminar air flow (ESCO), pembakar Bunsen, dan perforator.

Sampel diidentifikasi oleh Bidang Botani, Pusat Penelitian Biologi, LIPIBogor. Ekstraksi rimpang Z. zerumbet menggunakan metode maserasi. Sampe dihaluskan dengan digiling menggunakan blender, selanjutnya diayak menggunakan ayakan berukuran 40 mesh. Sebanyak 50 gram simplisia diekstraksi mengunakan pelarut n-heksana, etil asetat, dan etanol masing-masing sebanyak $150 \mathrm{~mL}$ selama 24 jam pada suhu ruang, sedangkan untuk pelaru akuades dilakukan pemanasan dengan suhu $=80^{\circ} \mathrm{C}$ selama 2 jam. Filtrat hasil maserasi disaring dan dipekatkan dengan rotavapor vakum pada suhu $60^{\circ} \mathrm{C}$

Uji aktivitas antibakteri dilakukan dengan metode difusi agar (sumuran) dengan merujuk pada metode Kader et al. 2011. Bakteri-bakteri patogen Gram negatif (E. coli dan P. Aeruginosa) dan Gram positif (S. aureus dan B. subtilis) diperoleh dari koleksi Laboratorium Bakteriologi Fakultas Kedokteran Hewan IPB. Inokulan bakteri ditumbuhkan pada media Nutrien Agar (NA) (OxoidTM). Biakan bakteri kemudian diencerkan dengan $\mathrm{NaCl} 0.85 \%$ menggunakan metode McFarland 0.5 (setara dengan $10^{8} \mathrm{CFU} \mathrm{mL}{ }^{-1}$ ). Sebanyak $0.1 \mathrm{~mL}$ masing-masing suspensi bakteri yang telah diencerkan kemudian dicampurkan ke dalam $20 \mathrm{~mL}$ media Mueller-Hinton Agar (MHA) (OxoidTM) suhu $\pm 45^{\circ} \mathrm{C}$. Setelah memadat, media dilubangi dengan cork borrer berdiameter $5.3 \mathrm{~mm}$. Sebanyak $50 \mu \mathrm{L}$ dari masing-masing ekstrak dimasukkan ke dalam sumuran. Uji aktivitas antibakter masing-masing ekstrak dilakukan pada konsentrasi $500 \mathrm{mg} \mathrm{mL}^{-1}$. Fosfomisin 0.4 $\mathrm{mg} \mathrm{mL}^{-1}$ digunakan sebagai kontrol positif dan akuades steril sebagai kontro negatif. Selanjutnya diinkubasi pada suhu $37^{\circ} \mathrm{C}$ selama $24 \mathrm{jam}$. Zona bening yang terlihat di sekeliling lubang menjadi petunjuk adanya aktivitas antibakteri dan merupakan zona hambat dari ekstrak tanaman $Z$. zerumbet. Zona bening tersebut kemudian diukur menggunakan jangka sorong.

Ekstrak yang menunjukkan aktivitas terbaik kemudian diukur nilai konsentrasi hambat tumbuh minimum (KHTM). Pengujian KHTM dilakukan menggunakan metode difusi agar dengan prosedur sama seperti yang telah dijelaskan sebelumnya. Penentuan KHTM dilakukan dengan membuat konsentrasi yang bervariasi yaitu 5, 10, 25, 50, 100, 150, dan $250 \mathrm{mg} \mathrm{mL}^{-1}$.

Ekstrak dengan aktivitas antibakteri terbaik selanjutnya diuji fitokimia untuk mengetahui secara kualitatif kandungan senyawa bioaktifnya. Uji ini meliputi uji fenolik hidrokuinon, flavonoid, alkaloid, saponin, tanin dan triterpenoid-steroid, (Harborne, 1996)

Analisis kandungan senyawa yang terkandung pada ekstrak teraktif dilakukan menggunakan Liquid chromatography mass spectra (LCMS) d Laboratorium Kesehatan Daerah DKI Jakarta. Spesifikasi instrumen yang digunakan adalah Qmicro QAA 642, dengan ion mode adalah $\mathrm{ES}^{+}$. Pelarut yang digunakan adalah metanol dan air dengan perbandingan 10:90 (v/v) dengan laju alir $0.20 \mathrm{~mL} \mathrm{mnt}^{-1}$, dan temperatur kolom sebesar $40^{\circ} \mathrm{C}$. Analisis kromatogram massa molekul ion puncak senyawa-senyawa terkandung dilakukan menggunakan database dari The Human Metabolome Database (HMDB).

\section{Hasil dan Pembahasan}

\subsection{Identifikasi Tumbuhan}

Berdasarkan hasil identifikasi, identitas sampel tumbuhan adalah Zingiber zerumbet (L.) Sm., famili Zingiberaceae. Morfologi tanaman ini ditampilkan pada Gambar 1. Z. zerumbet merupakan tanaman semak berumur tahunan (terna parennial). Tanaman ini tumbuh di daerah dataran rendah sampai ketinggian $1200 \mathrm{~m}$ di atas permukaan laut. Berdasarkan klasifikasi botaninya, tanaman ini termasuk ke dalam divisi Spermatophyta, subdivisi Angiospermae, kelas Monocotyledonae, bangsa Zingiberales, suku Zingiberaceae, genus Zingiber spesies Zingiber zerumbet 

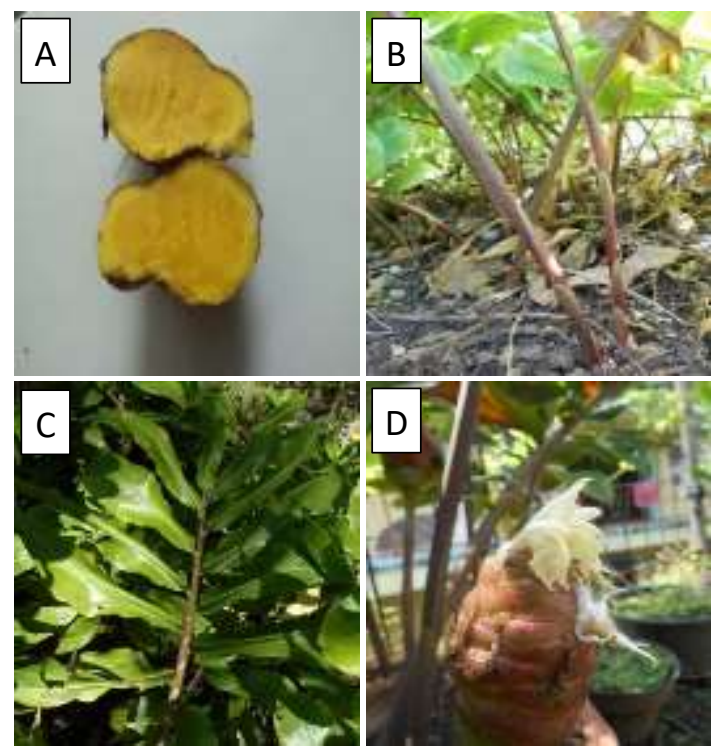

Gambar 1. Tanaman Z. zerumbet: A. Rimpang; B. Batang; C. Daun; D. Bunga

\subsection{Rendemen Ekstrak}

Rendemen ekstrak merupakan perbandingan antara bobot ekstrak yang dihasilkan dengan bobot sampel awal yang diekstrak. Persentasi rendemen ekstrak pada Tabel 1, memperlihatkan kemampuan pelarut air lebih besar dalam mengekstraksi komponen aktif tanaman Z. zerumbet, diikuti oleh pelarut etanol, etil asetat dan N-heksana.

Tabel 1 Persentasi rendemen ekstrak

\begin{tabular}{cccc}
\hline Pelarut & Bobot sampel $(\mathrm{g})$ & Bobot Ekstrak $(\mathrm{g})$ & Rendemen $(\% \mathrm{~b} / \mathrm{b})$ \\
\hline n-Heksana & 200 & 6.30 & 3.15 \\
Etil Asetat & 200 & 7.60 & 3.80 \\
Etanol & 100 & 6.20 & 6.20 \\
Air & 150 & 10.4 & 6.90 \\
\hline
\end{tabular}

3.3 Aktivitas Antibakteri Ekstrak N-Heksan, Etil Asetat, Etanol, dan Air

Ekstrak Z. zerumbet dinyatakan mempunyai aktivitas antibakteri jika terbentuk zona bening di sekeliling sumuran berisi ekstrak yang ditumbuhkan pada media yang telah diinokulasi oleh bakteri (Gambar 2.).
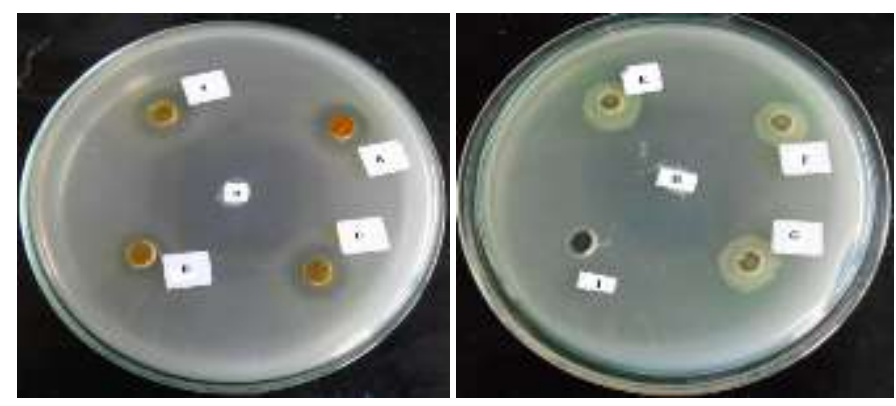

Keterangan: A: Konsentrasi ekstrak uji sebesar $250 \mathrm{mg} \mathrm{mL}^{-1}$; B. Konsentrasi ekstrak sebesar $150 \mathrm{mg} \mathrm{mL}^{-1}$; C. Konsentrasi ekstrak sebesar $100 \mathrm{mg} \mathrm{mL}^{-1}$; D. Konsentras ekstrak sebesar $50 \mathrm{mg} \mathrm{mL}^{-1}$; E. Konsentrasi ekstrak sebesar $25 \mathrm{mg} \mathrm{mL}^{-1}$; F. Konsentrasi ekstrak sebesar $10 \mathrm{mg} \mathrm{mL}^{-1}$; G. Konsentrasi ekstrak sebesar $5 \mathrm{mg}$ $\mathrm{mL}^{-1}$; H. Kontrol positif; I. Kontrol negatif

Gambar 2. Zona bening yang terbentuk pada ekstrak etanol tanaman Z. zerumbet ketika diuji terhadap bakteri $S$. aureus

Diameter hambat merupakan ukuran kekuatan hambatan substansi antibakteri. Lebarnya diameter zona bening yang terbentuk ditentukan oleh konsentrasi senyawa yang menjadi dasar pengujian kuantitatif dan mengindikasikan bahwa senyawa tersebut bisa bebas berdifusi ke seluruh medium. Hasil uji aktivitas antibakteri ekstrak Z. zerumbet dapat dilihat pada Tabel 2. Hasil uji menunjukkan bahwa ekstrak etanol memiliki diameter hambat yang lebih besar dibanding ekstrak n-Heksan, etil asetat, dan air.

Tabel 2 Hasil uji aktivitas antibakteri

\begin{tabular}{ccccc}
\hline \multirow{2}{*}{ Ekstrak } & \multicolumn{4}{c}{ Diameter zona hambat $(\mathrm{mm})$ pada bakteri } \\
\cline { 2 - 5 } & E. coli & P. aeruginosa & B. subtilis & S. aureus \\
\hline N-Heksana & $\mathbf{3 . 4 5}(\mathrm{R})$ & $4.40(\mathrm{R})$ & $14.14(\mathrm{I})$ & $7.98(\mathrm{R})$ \\
Etil Asetat & $1.54(\mathrm{R})$ & $6.20(\mathrm{R})$ & $10.82(\mathrm{R})$ & $8.02(\mathrm{R})$ \\
Etanol & $3.42(\mathrm{R})$ & $\mathbf{7 . 8 8}(\mathrm{R})$ & $\mathbf{1 5 . 2 2}(\mathrm{I})$ & $\mathbf{8 . 1 2}(\mathrm{R})$ \\
Air & $2.31(\mathrm{R})$ & $5.30(\mathrm{R})$ & $8.53(\mathrm{R})$ & $3.03(\mathrm{R})$ \\
\hline
\end{tabular}

Keterangan: S (susceptible): $\geq 16 \mathrm{~mm}, \mathrm{I}$ (intermediate): $13-15 \mathrm{~mm}, \mathrm{R}$ (resistant) $: \leq 12 \mathrm{~mm}$ (CLSI, 2007)

\subsection{Konsentrasi Hambat Tumbuh Minimun Ekstrak Etanol}

Uji KHTM merupakan upaya mencari konsentrasi terendah yang masih mampu menghambat pertumbuhan organisme mikroba. Hasil uji KHTM ekstrak etanol tanaman Z. zerumbet dapat dilihat pada Tabel 3. Terlihat bahwa KHTM ekstrak etanol dalam keempat bakteri uji terjadi untuk bakteri Gram positif $S$. aureus pada konsentrasi $50 \mathrm{mg} \mathrm{mL}^{-1}$

Tabel 3 Hasil uji KHTM ekstak etanol Z. zerumbet

\begin{tabular}{ccccc}
\hline Konsentrasi & \multicolumn{4}{c}{ Luas zona hambat $(\mathrm{mm})$ pada bakteri } \\
\cline { 2 - 5 } $\begin{array}{c}\text { ekstrak etanol } \\
\left(\mathrm{mg} \mathrm{mL}^{-1}\right)\end{array}$ & Ps. Aeruginosa & E. coli & B. subtilis & S.aureus \\
\hline 250 & $2.59(\mathrm{R})$ & $2.89(\mathrm{R})$ & $3.42(\mathrm{R})$ & $7.71(\mathrm{R})$ \\
150 & - & $1.98(\mathrm{R})$ & $2.72(\mathrm{R})$ & $7.13(\mathrm{R})$ \\
100 & - & - & $2.27(\mathrm{R})$ & $6.12(\mathrm{R})$ \\
50 & - & - & - & $3.85(\mathrm{R})$ \\
$\mathrm{K}+$ & $8.96(\mathrm{R})$ & $29.66(\mathrm{~S})$ & $11.59(\mathrm{R})$ & $27.92(\mathrm{~S})$ \\
$\mathrm{K}-$ & - & - & - & - \\
\hline Keterangan: S (susceptible) $: \geq 16 \mathrm{~mm}$, I (intermediate) $: 13-15 \mathrm{~mm}, \mathrm{R}($ resistant $): \leq 12 \mathrm{~mm}$
\end{tabular}
(CLSI, 2007)

\subsection{Hasil Uji Fitokimia}

Uji fitokimia bertujuan untuk mengetahui kandungan senyawa metabolit sekunder dan golongan senyawa bioaktif yang terkandung di dalam ekstrak. Dari hasil uji fitokimia ini dapat diduga golongan senyawa yang berperan sebagai antibakteri. Hasil uji fitokimia mengindikasikan ekstrak etanol Z. zerumbet mengandung senyawa-senyawa terpenoid, flavonoid, tanin dan fenolik (Tabel 4).

Tabel 4 Hasil uji fitokimia ekstrak etanol Z. zerumbet

\begin{tabular}{cccc}
\hline Uji Golongan & Reagent & Perubahan yang terjadi & Ket \\
\hline Fenolik & $\mathrm{FeCl}_{3} 5 \%$ & Hijau & + \\
Triterpenoid dan & Lieberman Burchard & Merah & + \\
Steroid & Dragendorff & & \\
& Mayer & Tidak terlihat endapan & - \\
Alkaloid & Wagner & & \\
& Water & Busa tidak stabil & - \\
Saponin & $\mathrm{FeCl}_{3} 1 \%$ & Biru Pekat & + \\
Tanin & $\mathrm{H}_{2} \mathrm{SO}_{4}$ & Jingga & + \\
Flavonoid & $\mathrm{tang}^{2}$ & &
\end{tabular}

\subsection{Analisis Kandungan Senyawa Ekstrak Etanol}

Hasil analisis memperlihatkan adanya 3 puncak dengan waktu retensi berturut-turut sebesar 1.448, 15.929 dan 22.062 dengan persentasi kelimpahan berturut-turut sebesar $46.25 \%, 34.375 \%$ dan $100 \%$. Analisis kromatogram ekstrak kasar etanol menunjukkan fragment ion puncak pada $\mathrm{m} / \mathrm{z} 717.41,679.26$, dan 219.12.

Analisis massa molekul ion puncak menggunakan database dari The Human Metabolome Database (HMDB) berdasarkan mode ionisasi positif menunjukkan bahwa senyawa dengan m/z 717 belum diketahui, m/z 679 adalah senyawa gingerglikolipid B (2-hydroxy-3-\{[3,4,5-trihydroxy-6-(\{[3,4,5-trihydroxy-66 (hydroxymethyloxan-2-yl]oxy\}methyl)oxan2-yl]oxy\}propyl(9Z,12Z)octadeca-9,12-dienoate), dan m/z 219 tersebut adalah zerumbon $((2 E, 6 E, 10 E)$ 2,6,9,9-tetramethyl-2,6,10-cycloundecatrienone).

\subsection{Pembahasan}

Z. zerumbet memiliki ukuran rimpang yang besar berwarna kuning gading, dengan rasa yang cukup pahit, agak pedas, dan bau yang khas dari senyawa aromatik (spice taste) (Gambar 1A). Tinggi tanaman berkisar 1.500-1.800 cm. Memiliki batang semu dan tumbuh tegak serta berwarna kemerahan (Gambar 1B). Daunnya berbentuk obovate (bulat telur terbalik) dengan pangkal daun membulat dan ujung daunnya agak meruncing (subacuminate). Daun bertrikom halus (subglabrous) serta memiliki tangkai (petiole) bermembran, ligula bermembran, dan pelepah (sheath) (Gambar 1C). Bunga tanaman tumbuh dari pangkal rimpang berbentuk seperti bonggol (cone), dan bunganya berwarna kuning pucat (Gambar 1D). Braktea merupakan kantong tempat munculnya bunga dimana satu bunga dalam satu braktea. Braktea berwarna hijau sewaktu muda dan berubah warna menjadi merah. Perubahan warna menjadi merah terjadi setelah pembuahan (Larsen et al. 1999).

Persentasi rendemen ektrak pada Tabel 1, memperlihatkan kemampuan pelarut air lebih besar dalam mengekstraksi komponen aktif tanaman $Z$. zerumbet, diikuti oleh pelarut etanol, etil asetat dan N-heksana. Rendemen ekstrak air yang lebih besar kemungkinan dipengaruhi oleh polaritasnya. Polaritas relatif pelarut dapat dilihat dari nilai konstanta dielektrik masingmasing pelarut. Polaritas pelarut air adalah sebesar 0.90 yang mana lebih besar dari pelarut etanol (0.68), etil asetat (0.38) dan heksana (0.00) (Yasni, 2013). Hal ini menunjukkan rendemen ekstrak makin meningkat seiring meningkatnya kepolaran pelarut. Tingginya kemampuan pelarut air dalam mengekstraksi komponen aktif berkaitan dengan polaritas $(\varepsilon)$ pelarut yang berarti komponen senyawa yang terkandung dalam rimpang $Z$. zerumbet sebagian besar merupakan senyawa polar. Sifat kepolaran senyawa dilihat dari gugus polarnya seperti gugus $\mathrm{OH}, \mathrm{COOH}$, dan lain-lain. Hal lain yang memperbesar kemampuan pelarut air dalam menarik komponen aktif adalah proses ekstraksi yang menggunakan 
pemanasan pada suhu $80^{\circ} \mathrm{C}$ yang mana proses pemanasan akan memperbesar kelarutan.

Pengujian aktivitas antibakteri ekstrak masing-masing dilakukan pada konsentrasi $500 \mathrm{mgmL}^{-1}$ untuk mengetahui ada atau tidaknya kemampuan ekstrak tanaman menghambat pertumbuhan bakteri patogen. Kontrol positif yang digunakan adalah fosfomisin, sedangkan kontrol negatif yang digunakan adalah aquadest. Fosfomisin diketahui bekerja menghambat sintesis peptidoglikan pada biosintesis dinding sel bakteri (Skarzynski et al. 1996). Ekstrak Z. zerumbet dinyatakan mempunyai aktivitas antibakteri jika terbentuk zona bening di sekeliling sumuran berisi ekstrak yang ditumbuhkan pada media yang telah diinokulasi oleh bakteri. Dari data pada Tabel 2. terlihat bahwa ekstrak etanol memberikan batas daerah hambat yang terefektif dengan diameter terbesar adalah $15.22 \mathrm{~mm}$ pada bakteri $B$. subtilis, dan diameter terkecil adalah $3.42 \mathrm{~mm}$ pada bakteri $E$. coli. Kader et al. (2011) melaporkan bahwa ekstrak kasar etanol $Z$. zerumbet dengan konsentrasi $400 \mu \mathrm{g}$ disk $^{-1}$ mampu menghambat 5 jenis bakteri Gram positif dan 8 jenis bakteri Gram negatif dengan luas zona hambat berkisar 6-10 mm.

Data penelitian menunjukkan bahwa ekstrak etanol Z. zerumbet lebih menghambat bakteri Gram positif ( $S$. aureus dan B. Subtilis) dibanding bakteri Gram negatif ( $E$. coli dan $P$. aeruginosa). Hal ini kemungkinan dipengaruhi oleh perbedaan komposisi dan struktur pada dinding sel bakteri Gram positif dan Gram negatif. Struktur dinding sel bakteri Gram positif lebih sederhana, yakni berlapis tunggal ( $90 \%$ peptidoglikan) dengan ketebalan bervariasi antara 20-40 $\mathrm{nm}$ (Kim et al. 2015) dengan kandungan lipid yang rendah (1-4\%) sehingga memudahkan bahan bioaktif masuk ke dalam sel. Sementara itu, struktur dinding sel bakteri negatif lebih kompleks, yaitu berlapis tiga terdiri dari lapisan luar lipoprotein, lapisan tengah lipopolisakarida yang berperan menghalangi masuknya bahan bioaktif antibakteri (Griffin 2000), dan lapisan dalam berupa peptidoglikan yang berkisar 5-10\% $(6.25 \pm 0.53 \mathrm{~nm}$ untuk $E$. coli dan $2.41 \pm 0.54$ nm untuk Ps. aeruginosa) dengan kandungan lipid tinggi (11-12\%) (Vollmer dan Seligman 2010)

Data pada Tabel 3. menunjukkan nilai KHTM terendah terjadi pada bakteri S. aureus. S. aureus merupakan bakteri Gram positif, yang memiliki 40 lapisan peptidoglikan yang merupakan $50 \%$ dari bahan penyusun dinding sel (Kim et al. 2015). Perhusip (2006) mengungkapkan bahwa setiap zat yang menghambat salah satu langkah dalam biosintesis peptidoglikan akan mengakibatkan dinding sel bakteri yang tumbuh menjadi rapuh sehingga sel akan mengalami lisis Rusaknya dinding sel atau terhambatnya sintesis oleh senyawa antibakteri mengakibatkan terbentuknya sel-sel yang peka terhadap tekanan osmosis, terutama pada bakteri Gram positif yang mana kekuatan dinding selnya berasal dari peptidoglikan. Tekanan osmosis dalam sel bakteri menyebabkan terjadinya lisis, yang merupakan dasar efek bakterisidal pada bakteri (Perhusip 2006).

Dari data hasil uji KHTM (Tabel 3.), memperlihatkan ekstrak etanol Z. zerumbet mempunyai aktivitas yang sedang. Ini berkaitan dengan kondisi ekstrak yang masih belum murni. Banyaknya senyawa yang terkandung dalam ekstrak kasar etanol ini mengakibatkan adanya sifat saling meniadakan (antagonis) antar senyawa dalam ekstrak sehingga mengurangi aktivitas antibakteri ekstrak etano Z. zerumbet. Pemisahan atau fraksinasi senyawa dalam ekstrak lebih lanjut berperan penting dalam meningkatkan kemampuan hambat terhadap bakteri Kader et al. (2011) melaporkan bahwa ekstrak etanol yang telah difraksinasi memiliki kemampuan hambat terendah sebesar 128-256 $\mu \mathrm{g} \mathrm{disk}^{-1}$ saat diujikan pada bakteri E. coli, P. aeruginosa, S. typhi, B. cereus, S. lutea, dan $V$. Parahemolyticus.

Uji fitokimia menggambarkan akan golongan senyawa yang terkandung dalam ekstrak. Hasil uji fitokimia mengindikasikan rimpang tanaman $Z$. zerumbet mengandung senyawa-senyawa terpenoid, flavonoid, tanin dan fenolik. Nag et al. (2013) melaporkan bahwa $Z$. zerumbet yang berasal dari wilayah India mengandung sesquiterpenoid, flavonoid, senyawa-senyawa aromatik, vanillin, kaempferol dan senyawa turunannya, serta polifenol. Senyawa-senyawa golongan fenolik, saponin, dan terpenoid terkandung pada Z. zerumbet asal Bangladesh (Kader et al. 2011).

Senyawa-senyawa fenolik, flavanoid, tanin, dan terpenoid pada tanaman zingiberaceae diketahui memiliki aktivitas antibakteri (Nursal et al. 2006; Lawalata, 2012). Senyawa terpen merupakan senyawa antibakteri utama dalam rempah-rempah (Yasni, 2013). Terpenoid diketahui dapat bersifat sebagai antibakteri (Cowan, 1999). Mekanisme terpenoid sebagai antibakteri adalah bereaksi dengan fraksi lipid membran plasma bakteri yang mengakibatkan perubahan permeabilitas membran yang jika diakumulasikan terus-menerus dapat mengakibatkan lisisnya material intraseluler akibat terbentuknya rongga pada lipid bilayer (Griffin, 2000). Senyawa tanin dan flavonoid merupakan senyawa polifenol yang bersifat sebagai antibakteri (Cowan, 1999). Senyawa flavanoid dalam aktivitas kerjanya akan membentuk ikatan kompleks dengan dinding sel bakteri sehingga menurunkan permeabilitas dinding sel (Nagappan et al. 2011) dan merusak membran sel bakteri akibat sifat lipofiliknya (de Fatima et al. 2006). Demikian halnya tanin, tanin diduga berikatan dengan dinding sel bakteri sehingga akan menginaktifkan kemampuan menempel bakteri dan menghambat pertumbuhan bakteri (Cowan 1999).

Analisis massa molekul ion puncak menggunakan database dari The Human Metabolome Database (HMDB) berdasarkan mode ionisasi positif menunjukkan bahwa senyawa dengan $\mathrm{m} / \mathrm{z} 219$ tersebut adalah zerumbon $((2 E, 6 E, 10 E)-2,6,9,9$ tetramethyl-2,6,10-cycloundecatrienone). Abdul et al. (2008) mengemukakan bahwa massa ion fragmentasi terbesar $(218 \mathrm{~m} / \mathrm{z})$ sebanding dengan bobot molekul senyawa. Zerumbon merupakan konstituen terbesar pada rimpang tanaman dengan kelimpahan berkisar antara 12.6-73.1\% (Yob et al. 2011; Singh et al. 2012). Zerumbon mempunyai rumus kimia $\mathrm{C}_{15} \mathrm{H}_{22} \mathrm{O}$ dengan berat molekul sebesar 218.3346. Zerumbon adalah senyawa monosiklik sesquiterpen dan memiliki kekhasan dalam strukturnya dimana mempunyai suatu konjugasi silang keton pada 11 anggota cincinnya (Kitayama et al. 2003). Zerumbon memiliki tiga ikatan rangkap di mana ikatan rangkap pada posisi C-6 terisolasi sedangkan dua ikatan pada posisi C-2 dan C-10 terkonjugasi dalam sistem dienon. Ikatan rangkap pada $\mathrm{C}-10$ terkonjugasi silang dengan gugus karbonil pada struktur cincin beranggota 11. Gugus keton pada atom C-8 mengakibatkan zerumbon bersifat polar sehingga bisa terekstrak pada pelarut polar dan semi polar. Sifat polaritas senyawa merupakan sifat kimia yang sangat penting. Kepolaran ini berkaitan kelarutannya dalam air dan sifat hidrofilik sehingga zat antibakteri ini dapat larut dalam fase air dimana mikroba umumnya tumbuh dalam fase air

Abdul et al. (2008) melaporkan bahwa zerumbon memiliki aktivitas antibakteri pada $S$. choleraesuis tetapi tidak memiliki kemampuan menghambat pada pada bakteri resisten methicillin dari $S$. aureus, $P$. Aeruginosa, $S$ choleraesuis dan B. subtilis. Santosh Kumar et al. (2013) melaporkan bahwa konsentrasi KHTM zerumbon dalam menghambat bakteri B. cereus, S. aureus, E. coli, dan Y. Enterocolitica berturut-turut sebesar 100, 125, 75, dan $250 \mathrm{ppm}$ Senyawa sesquiterpena diketahui memiliki aktivitas antibakteri lebih baik pada bakteri Gram positif dari pada bakteri Gram negatif. Ini diduga berkaitan dengan dimilikinya membran luar pada bakteri Gram negatif yang mengelilingi dinding sel, dimana membatasi difusi senyawa hidrofilik melalui lipopolisakarida (Vollmer dan Seligman 2010).

Senyawa dengan massa molekul ion puncak m/z 679 juga menjadi penyusun ekstrak etanol tanaman. Analisis menggunakan database HMDB memberikan hasil bahwa senyawa tersebut adalah Gingerglikolipid B (2-hydroxy-3-\{[3,4,5trihydroxy-6-( $\{[3,4,5$-trihydroxy-6-6(hydroxymethyloxan-2-

yl]oxy\}methyl)oxan2-yl]oxy\}propyl(9Z,12Z)-octadeca-9,12-dienoate).

Senyawa ini memiliki rumus kimia $\mathrm{C}_{33} \mathrm{H}_{58} \mathrm{O}_{14}$ dengan berat molekul sebesar 678.8052. Gingerglikolipid B umumnya ditemukan sebagai senyawa penyusun pada tanaman Zingiber officinale dan diketahui bersifat sebagai anti borok (Yoshikawa et al. 1994). Gingerglikolipid B merupakan suatu monoasildigalaktosilgliserol.

Beragamnya senyawa-senyawa aktif yang terkandung pada tanaman $Z$. zerumbet dipengaruhi oleh kondisi lingkungan tanaman tersebut tumbuh. Pulau Timor merupakan wilayah berkarakteristik semi arid, dimana mengalami musim kering yang panjang dan musim penghujan yang pendek. Keadaan daerah yang beriklim semiarid mengakibatkan kondisi tanamannya berada dalam keadaan cekaman kekeringan dan suhu tinggi dengan intensitas penyinaran matahari lebih panjang (Selmar, 2008). Ini mengakibatkan tanaman yang tumbuh mengalami kondisi cekaman kekeringan. Kondisi stres abiotik ini mengakibatkan tanaman mengakumulasikan secara berlebih senyawa-senyawa metabolit tertentu yang berbeda dengan daerah lain sebagai toleransi akan kondisi tersebut (Sopandie, 2014).

\section{Simpulan}

Rimpang Z. zerumbet asal Pulau Timor yang diekstrak dengan pelarut air, etanol, etil asetat, dan n-heksana memiliki aktivitas antibakteri. Ekstrak etanol memiliki aktivitas antibakteri yang lebih besar daripada ekstrak lainnya. Nilai KHTM ekstrak etanol terhadap $S$. aureus, B. subtilis, E. coli, P. aeruginosa secara berurutan adalah 50,100,150, $250 \mathrm{mg} \mathrm{mL}^{-1}$. Hasil analisis LC-MS ekstrak etanol menunjukkan bahwa senyawa yang terkandung dalam ekstrak adalah zerumbon dan gingerglikolipid $\mathrm{B}$.

\section{Pustaka}

Abdul A B, Abdelwahab S I, Al-Zubairi A S, Elhassan M M, Murali S M. 2008. Anticancer and Antimicrobial Activities of Zerumbone from The Rhizomes of Zingiber zerumbet. Int, J. Pharmacol., 4 (4): 301-304

Clinical and Laboratory Standards Institute (CLSI). 2007. Performance Standards for Antimicrobial Susceptibility Testing; Seventeenth Informational Supplement. M100-S17. Vol. 27 No. 1

Cowan M M. 1999. Plant Products as Antimicrobial Agents. Clin. Microbiol. Rev. Vol 12, No. 4

de Fatima A, Modo LV, Conegero LS, Pilli RA, Ferreira CV, Kohn LK, de Carvalho JE. 2006. Lactones and Their Derivatives Biological Activities, Mechanism of Action and Potential Leads for Drugs Design. J. Med. Chem. (13): 3371-3384

Griffin S. 2000. Aspect of Antimicrobial Activity of Terpenoids and The Relationship to Their Molecular Structure [Disertation]. New South Wales (AU): University of Western Sidney

Harborne J B. 1996. Metode Fitokimia: Penuntun Cara Modern Menganalisis Tumbuhan, Diterjemahkan oleh Kosasih Padmawinata dan Iwang Soediro. Bandung (ID): Penerbit ITB

Kader M G, Nikkon F, Rashid M A, Yeasmin T. 2011. Antimicrobial Activities of The Rhizome Extract of Zingiber zerumbet Linn. Asian Pac J Trop Biomed. 1(5):409-412

Kim SJ, Chang J, Singh M. 2015. Peptidoglycan Architecture of Gram-positive Bacteria by Solid-state NMR. Biochim Biophys Acta. 1848: 350-362. doi 10.1016/j.bbamem.2014.05.031

Kitayama T, Yokoi T, Kawai Y, Hill RK, Morita M, Okamoto T, Yamamoto K, Fokin VV, Sharpless KB, Sawada S. 2003. Chemistry of Zerumbone. Par 
5: Structural Transformation of The Dimethylamine Derivatives. Tetrahedron. 59: 4857-4866

Kress WJ, Prince LM, Wiliam KJ. 2002. Phylogeny and A New Classification of The Gingers (Zingiberaceae): Evidance from Molecular Data. Am. J. Botany 89 (11): 1682-1696.

Kress WJ, 2014. Zingiberales Research Website. Washington DC, USA: Smithsonian Institution.

Larsen K, Ibrahim H, Khaw SH, Saw LG. 1999. Pollination and Seed Dispersal, p. 19-20. In: K. M. Wong (Ed.). Ginger of Penninsula Malaysia and Singapura. Natural History Publication (Borneo). Kinabalu

Lawalata V N. 2012. Rekayasa Proses Ekstraksi Kulit Buah Langsat (Lansium domesticum var. langsat) sebagai Bahan Antibakteri dan Antioksidan. [disertasi].Bogor (ID): Program pascasarjana, Institut Pertanian Bogor

Nag A, Bandyopadhyay M, Mukherjee A. 2013. Antioxidant Activities and Cytotoxicity of Zingiber zerumbet (L.) Smith Rhizome. J Pharmacogn Phytochem. 2 (3): 102-108

Nagori BP, Solanki R. 2011. Role of Medicinal Plants in Wound Healing. Res. J. Med. Plant. 5 (4): 392-405, 2011

Nursal W, Sri, Wilda S. 2006. Bioaktifitas Ekstrak Jahe (Zingiber officinale Roxb.) dalam Menghambat Pertumbuhan Koloni Bakteri Escherichia coli dan Bacillus subtilis. Jurnal Biogenesis 2(2): 64-66

Parhusip AJN. 2006. Kajian Mekanisme Antibakteri Ekstrak Andaliman (Zanthoxylum acanthopodium DC) Terhadap Bakteri Patogen Pangan [disertasi]. Bogor (ID): Sekolah Pascarjana Institut Pertanian Bogor.

Santosh Kumar SC, Srinivas P, Negi PS, Bettadaiah BK. 2013. Antibacterial and Antimutagenic Activities of Novel Zerumbone Analogues. Food Chem., 141: 1097-1103

Sari KIP, Periadnadi, Nasir N. 2013. Uji Antimikroba Ekstrak Segar Jahe-Jahean (Zingiberaceae) Terhadap S. aureus, E. coli dan C. albicans. J. Bio. UA. 2 (1)-Maret 2013

Selmar D. 2008. Potensial of Salt and Drought Stress to Increase Pharmaceutical Significant Secondary Coumpounds in Plants. Agriculture and forestry research. 58:139-144

Sinaga E, Suprihatin, Wiryanti I. 2011. Perbandingan Daya Sitotoksik Ekstrak Rimpang 3 Jenis Tumbuhan Zingiberaceae Terhadap Sel Kanker MCF-7. Jurnal Farmasi Indonesia Vol. 5 No. 3. Januari 2011: 125-133

Singh CB, Nongalleima Kh, Brojendrosingh S, Ningobam S, Lokendrajit N, Singh LW. 2012 Biological and Chemical Properties of Zingiber zerumbet Smith: A Review. Phytochem Rev. 11:113-125

Skarzynski T, Mistry A, Wonacott A, Hutchinson SE, Kelly VA, Duncan K. 1996. Structure of UDP-N-acetylglucosamine enolpyruvyl transferase, An Enzyme Essential for The Synthesis of Bacterial Peptidoglycan, Complexed with Substrate UDP-N-acetylglucosamine and The Drug Fosfomycin. Structure. 4: 1465-1474.

Sopandie D. 2014. Fisiologi Adaptasi Tanaman Terhadap Cekaman Abiotik pada Agroekositem Tropika. Bogor (ID): IPB Press

Vollmer W, Seligman SJ. 2010. Architecture of Peptidoglycan: More Data and More Models. Trend in Microbiol. Vol 18, No. 2

Voravuthikuncai SP, Limsuwan S, Supapol O, Subhadhirasakul S. 2006. Antibacterial Activity of Extracts from Family Zingiberaceae Against Foodborne Pathogens. J Food Safety. 26: 325-334.

Yasni S. 2013. Teknologi Pengolahan dan Pemanfaatan Produk Ekstraktif Rempah. Bogor: IPB Press.

Yob N J, Jofrry S. M, Affandi M M R, Teh L K, Salleh M Z, Zakaria Z A. 2011. Zingiber zerumbet (L.) Smith: A Review of Its Ethnomedicinal, Chemical, and Pharmacological Uses. Doi: 10.1155/2011/543216

Yoshikawa M, Yamaguchi S, Kunimi K, Matsuda H, Okuno Y, Yamahara J, Murakami N. 1994. Stomachic Principles in Ginger III. An Anti-ulcer Principle, 6-Gingesulfonic acid, and Three Monoacyldigalactosylglycerols, Gingerglycolipids A, B, and C, from Zingiberis Rhizoma Originating in Taiwan. Chem Pharm Bull. 42 (6) 1226-1230 